Research article

\title{
On the performance of electrocatalytic anodes for photoelectro-Fenton treatment of synthetic solutions and real water spiked with the herbicide chloramben
}

\author{
Abdoulaye Thiam $^{\mathrm{a}}$, Ignasi Sirés ${ }^{\mathrm{b}, *}$, Ricardo Salazarc, Enric Brillas ${ }^{\mathrm{b}, * *}$ \\ a Programa Institucional de Fomento a la I+D+i, Universidad Tecnológica Metropolitana, Ignacio Valdivieso 2409, P.O. Box 8940577, San Joaquín, Santiago, Chile \\ ${ }^{\mathrm{b}}$ Laboratori d'Electroquímica dels Materials i del Medi Ambient, Departament de Química Física, Universitat de Barcelona, Martí i Franquès 1-11, 08028, Barcelona, Spain \\ ${ }^{\mathrm{c}}$ Laboratorio de Electroquímica del Medio Ambiente, LEQMA, Facultad de Química y Biología, Universidad de Santiago de Chile, USACh, Casilla 40, Correo 33, Santiago, Chile
}

\section{A R T I C L E IN F O}

Keywords:

Chloramben

Dimensionally stable anode

Oxidation products

Photoelectro-Fenton

Urban wastewater

\begin{abstract}
A B S T R A C T
The destruction of the herbicide chloramben in $0.050 \mathrm{M} \mathrm{Na}_{2} \mathrm{SO}_{4}$ solutions at natural $\mathrm{pH}$ has been studied by photoelectro-Fenton with UVA light (PEF). The trials were carried out in a cell equipped with an air-diffusion cathode for $\mathrm{H}_{2} \mathrm{O}_{2}$ generation and different electrocatalytic anodes, namely active $\mathrm{IrO}_{2}$-based and $\mathrm{RuO}_{2}$-based electrodes and non-active boron-doped diamond (BDD) and $\mathrm{PbO}_{2}$ ones. Similar removal rates were found regardless of the anode nature because the herbicide was mainly oxidized by ${ }^{\bullet} \mathrm{OH}$ formed from Fenton's reaction, which was enhanced by UVA-induced photo-Fenton reaction. The use of an $\mathrm{IrO}_{2}$-based anode led to almost total mineralization at high current density, as also occurred with the powerful BDD anode, since photoactive intermediates originated from ${ }^{\bullet} \mathrm{OH}$-mediated oxidation were degraded under irradiation with UVA light. The good performance of the $\mathrm{IrO}_{2}$-based anode in PEF was confirmed at different current densities and herbicide concentrations. The presence of $\mathrm{Cl}^{-}$in the medium caused a slight deceleration of herbicide removal as well as mineralization inhibition, owing to the production of active chlorine with consequent formation of persistent chloroderivatives. Seven aromatic products along with oxalic and oxamic acids were identified in sulfate medium. Five aromatic derivatives were detected in $\mathrm{Cl}^{-}$-containing matrix, corroborating the generation of organochlorine compounds. In secondary effluent, larger mineralization was achieved by PEF with a BDD anode due to its high oxidation ability to destroy the chloroderivatives, although an acceptable performance was also obtained using an $\mathrm{IrO}_{2}$-based anode.
\end{abstract}

\section{Introduction}

The concern about water pollution by persistent organic pollutants is growing in parallel to the development of more efficient advanced oxidation processes (AOPs) for their destruction (Antonopoulou et al., 2014; Oturan and Aaron, 2014; Fernández-Castro et al., 2015; Johnson et al., 2017). Reactive oxygen species (ROS) such as hydroxyl radical $\left({ }^{*} \mathrm{OH}\right)$ generated on site account for the high oxidation power of AOPs. With a standard potential $E^{\mathrm{o}}=2.8 \mathrm{~V} / \mathrm{SCE},{ }^{\circ} \mathrm{OH}$ is the second strongest oxidant known, being able to attack non-selectively most organics until overall mineralization is attained (Oturan and Aaron, 2014;

Fernández-Castro

et al., 2015). Fenton process, in which a mixture of $\mathrm{Fe}^{2+}$ and $\mathrm{H}_{2} \mathrm{O}_{2}$ originates homogeneous ${ }^{\circ} \mathrm{OH}$ in the bulk from the classical Fenton's reaction (1) with optimum $\mathrm{pH}$ near 3 , is one of the most successful AOPs (Pignatello et al., 2006; Guinea et al., 2009; Ponnusami and Muthukumar, 2014; Matavos-Aramyan and Moussavi, 2017):

$\mathrm{Fe}^{2+}+\mathrm{H}_{2} \mathrm{O}_{2} \rightarrow \mathrm{Fe}^{3+}+\mathrm{OH}+\mathrm{OH}^{-}$

The poor $\mathrm{Fe}^{2+}$ regeneration from simultaneous Fenton-like reaction between $\mathrm{Fe}^{3+}$ and $\mathrm{H}_{2} \mathrm{O}_{2}$, the formation of Fe-rich sludge with loss of catalytic power, and the generation of refractory $\mathrm{Fe}(\mathrm{III})$-carboxylate complexes are the main drawbacks of this method.

\footnotetext{
* Corresponding author.

** Corresponding author.

Email addresses: i.sires@ub.edu (I. Sirés); brillas@ub.edu (E. Brillas)
} 
These problems can be partially solved using the photo-Fenton process, where the solution is illuminated with UV light (Pignatello et al., 1999; Southworth and Voelker, 2003; Rahim Pouran et al., 2015; Seibert et al., 2017). The incident photons can photodecarboxylate the Fe(III) complexes according to general reaction (2), largely enhancing the mineralization process (Seibert et al., 2017). Additionally, a faster production of - $\mathrm{OH}$ is achieved from photoreduction of $\mathrm{Fe}(\mathrm{OH})^{2+}$ species via reaction (3) (Pignatello et al., 1999; Southworth and Voelker, 2003).

$$
\mathrm{Fe}(\mathrm{COOR})^{2+}+h v \rightarrow \mathrm{Fe}^{2+}+\mathrm{CO}_{2}+\mathrm{R}
$$

$\mathrm{Fe}(\mathrm{OH})^{2+}+h v \rightarrow \mathrm{Fe}^{2+}+\mathrm{OH}$

Alternative electrochemical AOPs (EAOPs) such as electro-Fenton (EF) and photoelectro-Fenton with UVA light (PEF) have been more recently developed (Brillas et al., 2009; Brillas, 2014; Sirés et al., 2014; Martínez-Huitle et al., 2015; Moreira et al., 2017). These processes show several advantages compared to non-electrochemical counterparts, like the use of smaller catalytic $\mathrm{Fe}^{2+}$ contents because regeneration is feasible from cathodic reduction of $\mathrm{Fe}^{3+}$ by reaction (4) (Dirany et al., 2012):

$\mathrm{Fe}^{3+}+e^{-} \rightarrow \mathrm{Fe}^{2+}$

A key feature of Fenton-based electrochemical treatments is the continuous generation of $\mathrm{H}_{2} \mathrm{O}_{2}$ from cathodic $\mathrm{O}_{2}$ reduction by reaction (5). Typical carbonaceous cathodes used for this are graphite felt (Vatanpour et al., 2009), carbon felt (Dirany et al., 2012; El-Ghenymy et al., 2014; Yahya et al., 2014; Dominguez et al., 2018), activated carbon fiber (Wang et al., 2008), carbon modified with metals (Assumpção et al., 2013), carbon nanotubes (Khataee et al., 2013, 2014), boron-doped diamond (BDD) (Cruz-González et al., 2010, 2012), and carbon-polytetrafluoroethylene (PTFE) employed in $\mathrm{O}_{2}$ - or air-diffusion devices (Salazar et al., 2012: Coria et al., 2016; Galia et al., 2016; Steter et al., 2018).

$\mathrm{O}_{2}(g)+2 \mathrm{H}^{+}+2 e^{-} \rightarrow \mathrm{H}_{2} \mathrm{O}_{2}$

In an undivided cell, organic pollutants at $\mathrm{pH} 3$ are destroyed by homogeneous ${ }^{\bullet} \mathrm{OH}$ formed from Fenton's reaction (1) in EF, along with that induced by photolytic reaction (3) in PEF. Moreover, organics can be attacked by heterogeneous $\mathrm{M}\left({ }^{\bullet} \mathrm{OH}\right)$ originated from water discharge at the anode M via reaction (6) at high current (Brillas et al., 2009; Sirés et al., 2014). In the absence catalyst, the process is known as electrochemical oxidation with electrogenerated $\mathrm{H}_{2} \mathrm{O}_{2}$ (EO- $\mathrm{H}_{2} \mathrm{O}_{2}$ ) (Sirés et al., 2014; Martínez-Huitle et al., 2015).

$\mathrm{M}+\mathrm{H}_{2} \mathrm{O} \rightarrow \mathrm{M}(\cdot \mathrm{OH})+\mathrm{H}^{+}+\mathrm{e}^{-}$

Other oxidants can be produced depending on the dissolved salts. When the medium contains $\mathrm{Cl}^{-}$, as occurs in natural water and industrial wastewater, this anion is anodically oxidized to active chlorine species $\left(\mathrm{Cl}_{2} / \mathrm{HClO}\right)$ via reactions (7) and (8), which destroy the organic matter synergistically with hydroxyl radicals (Sirés et al., 2014; Martínez-Huitle et al., 2015: Moreira et al., 2017).
$2 \mathrm{Cl}^{-} \rightarrow \mathrm{Cl}_{2}(\mathrm{aq})+2 \mathrm{e}^{-}$

$\mathrm{Cl}_{2}(\mathrm{aq})+\mathrm{H}_{2} \mathrm{O} \rightarrow \mathrm{HClO}+\mathrm{Cl}^{-}+\mathrm{H}^{+}$

The oxidation power of $\mathrm{EO}-\mathrm{H}_{2} \mathrm{O}_{2}, \mathrm{EF}$ and $\mathrm{PEF}$ also depends on the nature of the anode, which can behave as active or non active. In EO- $\mathrm{H}_{2} \mathrm{O}_{2}$, the best material in a non-chlorinated matrix is the non-active $\mathrm{BDD}$ electrode because it yields high quantities of $\operatorname{BDD}\left({ }^{\bullet} \mathrm{OH}\right)$. This radical is more reactive than $\mathrm{M}\left({ }^{\bullet} \mathrm{OH}\right)$ formed at active anodes like $\mathrm{PbO}_{2}$ and dimensionally stable anodes (DSA ${ }^{\circledR}$ ) due to the weaker adsorption (Sirés et al., 2014; Coria et al., 2016; Steter et al., 2016). In chlorinated media, however, $\mathrm{IrO}_{2}$-based and $\mathrm{RuO}_{2}$-based $\mathrm{DSA}^{\circledR}$ originate large amounts of active chlorine, which attacks the organic molecules in concomitance with $\mathrm{M}\left({ }^{*} \mathrm{OH}\right)$, yielding chloroderivatives that are highly stable against oxidation (Steter et al., 2016; Thiam et al., 2015, 2018). In earlier works, our group has reported the predominant role of UVA radiation as compared to the influence of the anode in PEF, due to the potential photodegradation of intermediates formed during the degradation of drugs (Coria et al., 2016), dyes (Thiam et al., 2015), chemicals (Steter et al., 2016, 2018) and pesticides (Thiam et al., 2018). Nonetheless, more research is still required to provide sound conclusions on the viability of low cost DSA ${ }^{\circledR}$ in PEF regardless the reaction medium.

Chloramben (3-amino-2,5-dichlorobenzoic acid, $\mathrm{C}_{7} \mathrm{H}_{5} \mathrm{Cl}_{2} \mathrm{NO}_{2}$, $M=206.02 \mathrm{~g} \mathrm{~mol}^{-1}$ ) is a pre-emergence herbicide used to control the seedlings of annual grasses and broadleaf weeds. It is highly soluble in water (near $700 \mathrm{mg} \mathrm{L}^{-1}$ at $25^{\circ} \mathrm{C}$ ) and volatile, with tendency to contaminate groundwater. Chloramben has been detected in several U.S. states at $10 \mu \mathrm{g} \mathrm{L}^{-1}$ (Mir et al., 2012), being an irritant with moderate toxicity to honeybees and fishes. A reduced number of articles has reported the removal of chloramben either by photolysis in soils (Misra et al., 1997) and aqueous solutions (Bianco Prevot et al., 1999), or photocatalysis (Bianco Prevot et al., 1999; Mir et al., 2012). Using the latter AOP, total removal of $1.0 \mathrm{mM}$ herbicide in a $250 \mathrm{~mL}$ solution with $30 \mathrm{mM} \mathrm{H}_{2} \mathrm{O}_{2}$ was achieved after $45 \mathrm{~min}$ of irradiation of $\mathrm{TiO}_{2}$ with a $125 \mathrm{~W}$ UVC lamp, but with a decay $<20 \%$ of total organic carbon (TOC). Several by-products like 3-amino-5-chlorobenzoic, 2,5-dichlorobenzoic, chlorobenzoic and benzoic acids were detected by gas chromatography-mass spectrometry (GC-MS). However, there are no previous works on its destruction by EAOPs.

The aim of this article is to study the performance of PEF to degrade and mineralize chloramben solutions in order to show the viability of a DSA ${ }^{\circledR}$ electrode. The cell was an undivided tank reactor under UVA illumination, equipped with a carbon-PTFE air-diffusion cathode and a BDD, $\mathrm{PbO}_{2}, \mathrm{IrO}_{2}$-based or $\mathrm{RuO}_{2}$-based anode. $\mathrm{EO}-\mathrm{H}_{2} \mathrm{O}_{2}$ and $\mathrm{EF}$ trials were comparatively made to clarify the role of generated ${ }^{\circ} \mathrm{OH}$ and UVA light. The effect of current density and herbicide and chloride concentrations on PEF performance was examined. Aromatic intermediates and final carboxylic acids were identified by GC-MS and high-performance liquid chromatography (HPLC), respectively. The oxidation power of PEF with different anodes was finally assessed using urban wastewater spiked with chloramben, which showed the influence of ionic composition and natural organic matter (NOM) on the herbicide mineralization.

\section{Materials and methods}

\subsection{Chemicals}

Chloramben (95\% purity) was supplied by Sigma-Aldrich and used as received. Carboxylic acids were of analytical grade pur- 
chased from Panreac. The background electrolytes, $\mathrm{Na}_{2} \mathrm{SO}_{4}$ and $\mathrm{NaCl}$, and $\mathrm{FeSO}_{4} \cdot 7 \mathrm{H}_{2} \mathrm{O}$ used as catalyst source were of analytical grade from Fluka, Merck and Sigma-Aldrich, respectively. Other chemicals were either of analytical or HPLC grade supplied by Merck and Panreac. The synthetic solutions were prepared in ultrapure water (resistivity $>18.2 \mathrm{M} \Omega \mathrm{cm}$ ) from a Millipore Milli-Q system.

\subsection{Real wastewater sample}

Some electrolytic assays were carried out by spiking chloramben into urban wastewater. The fresh sample was collected from the secondary effluent of a wastewater treatment facility located in Gavà-Viladecans (Barcelona, Spain), preserved at $4{ }^{\circ} \mathrm{C}$ and filtered before use. The characteristics of this sample were: $\mathrm{pH}=7.9$, specific conductivity $=3.2 \mathrm{mS} \mathrm{cm}^{-1}$, total organic carbon (TOC) $=15.0 \mathrm{mg} \mathrm{L}^{-1}$, along with $318.1 \mathrm{mg} \mathrm{L}^{-1} \mathrm{Cl}^{-}, 141.3 \mathrm{mg} \mathrm{L}^{-1} \mathrm{SO}_{4}{ }^{2-}, 36.9 \mathrm{mg} \mathrm{L}^{-1} \mathrm{NH}_{4}{ }^{+}, 0.85 \mathrm{mg} \mathrm{L}^{-1}$ $\mathrm{NO}_{3}^{-}, 0.79 \mathrm{mgL}^{-1} \mathrm{NO}_{2}^{-}$, and $0.19 \mathrm{mgL}^{-1} \mathrm{Fe}^{2+}$ as main ions.

\subsection{Electrolytic systems}

The electrolytic cell was a conventional undivided, cylindrical, double-jacketed tank reactor of $150 \mathrm{~mL}$ capacity. External thermostated water was recirculated through the double jacket to maintain the solution at $35^{\circ} \mathrm{C}$, which ensured insignificant water evaporation. A solution volume of $100 \mathrm{~mL}$ was treated in each assay under vigorous stirring at $800 \mathrm{rpm}$ with a magnetic bar. One of the following four electrodes was used as the anode in each trial: (i) $\mathrm{IrO}_{2}$-based plate $\left(\mathrm{DSA}^{\circledR}-\mathrm{O}_{2}\right.$ ) purchased from NMT Electrodes, (ii) $\mathrm{RuO}_{2}$-based plate $\left(\mathrm{DSA}^{\circledR}-\mathrm{Cl}_{2}\right.$ ) purchased from NMT Electrodes, (iii) $\mathrm{PbO}_{2}$ synthesized using the electrodeposition procedure described in earlier work (Sirés et al., 2009; Recio et al., 2011), and (iv) BDD thin-film over Si purchased from NeoCoat. In all tests, the cathode was a carbon-PTFE air-diffusion electrode purchased from E-TEK, mounted as described elsewhere (Steter et al., 2016), to generate $\mathrm{H}_{2} \mathrm{O}_{2}$ by pumping $1 \mathrm{Lmin}^{-1}$ of air. The immersed area of each electrode was $3 \mathrm{~cm}^{2}$ and the anode-cathode separation was $1 \mathrm{~cm}$.

The EF and PEF treatments were carried out in the presence of $0.50 \mathrm{mM} \mathrm{Fe}{ }^{2+}$, since the catalyst concentration found as optimal for analogous studies with other organics was within the $0.5-1.0 \mathrm{mM}$ range (Almeida et al., 2012; Lanzalaco et al., 2017). The PEF experiments were run under irradiation of the solution with UVA light $(365 \mathrm{~nm})$ provided by a Philips TL/6W/08 fluorescent black light blue placed $5 \mathrm{~cm}$ above the solution (irradiance of $5 \mathrm{~W} \mathrm{~m}^{-2}$ ). Galvanostatic trials were made by applying a constant current density ( $j$ ) provided by an Amel 2049 potentiostat-galvanostat. Before the first assays, all the electrodes were electrochemically activated/cleaned under polarization in $0.050 \mathrm{M}$ $\mathrm{Na}_{2} \mathrm{SO}_{4}$ at $j=100 \mathrm{~mA} \mathrm{~cm}^{-2}$ for $240 \mathrm{~min}$.

\subsection{Apparatus and analytical procedures}

A Crison $2000 \mathrm{pH}$-meter was employed for $\mathrm{pH}$ measurement. Samples were withdrawn at regular time intervals from the treated solutions and microfiltered with $0.45 \mu \mathrm{m}$ PTFE membrane filters from Whatman to be immediately analyzed.

The herbicide concentration was determined by reversed-phase HPLC using a Waters system composed of a 600 LC and a photodiode array detector set at $\lambda=297 \mathrm{~nm}$. The LC was fitted with a BDS Hypersil C18 $6 \mu \mathrm{m}, 250 \mathrm{~mm} \times 4.6 \mathrm{~mm}$ (i.d.), column at $35^{\circ} \mathrm{C}$. Prior to do this analysis, the samples were diluted with methanol to stop the degradation process. The aliquots were injected into the LC under circulation of a 60:40 (v/v) acetonitrile/ water $\left(\mathrm{KH}_{2} \mathrm{PO}_{4} 10 \mathrm{mM}\right.$, pH 3) mixture at $0.8 \mathrm{~mL} \mathrm{~min}^{-1}$. The peak related to chloramben appeared in the chromatograms at retention time $\left(t_{\mathrm{r}}\right)$ of $4.6 \mathrm{~min}$.

The solution TOC was determined on a Shimadzu VCSN TOC analyzer by injecting $50 \mu \mathrm{L}$ samples. In this analysis, reproducible TOC values with $\pm 1 \%$ accuracy were found. From the TOC abatement $(\triangle T O C$, $\mathrm{mg} \mathrm{L} \mathrm{L}^{-1}$ ) determined at time $t(\mathrm{~h})$ of a given experiment performed at current $I$ (A), the mineralization current efficiency (MCE, \%) was estimated by the following equation (Thiam et al., 2015):

$\mathrm{MCE}=\frac{n F V(\Delta \mathrm{TOC})}{4.32 \times 10^{7} m I t} \times 100$

where $F$ is the Faraday constant $\left(96,485 \mathrm{Cmol}^{-1}\right), V$ is the solution volume (L), $4.32 \times 10^{7}$ is a factor for units homogenization $\left(3600 \mathrm{sh}^{-1} \mathrm{x}\right.$ $12,000 \mathrm{mgC} \mathrm{mol}^{-1}$ ) and $m=7$ is the number of carbon atoms of chloramben. An $n$-value of 24 was taken assuming the following total mineralization reaction of the herbicide to $\mathrm{CO}_{2}$, with $\mathrm{Cl}^{-}$and $\mathrm{NH}_{4}{ }^{+}$as pre-eminent ions:

$$
\begin{aligned}
\mathrm{C}_{7} \mathrm{H}_{5} \mathrm{Cl}_{2} \mathrm{NO}_{2}+12 \mathrm{H}_{2} \mathrm{O} \rightarrow & 7 \mathrm{CO}_{2}+2 \mathrm{Cl}^{-}+\mathrm{NH}_{4}^{+} \\
+ & 25 \mathrm{H}^{+}+24 \mathrm{e}^{-}
\end{aligned}
$$

The assays for assessing all decays were performed in triplicate, and average values are given along with the error bars corresponding to $95 \%$ confidence intervals in figures.

Primary aromatic intermediates formed at short electrolysis time of PEF treatments of $1.19 \mathrm{mM}$ chloramben solutions in $0.50 \mathrm{M} \mathrm{Na}_{2} \mathrm{SO}_{4}$ and $0.011 \mathrm{M} \mathrm{NaCl}+0.0015 \mathrm{M} \mathrm{Na}_{2} \mathrm{SO}_{4}$ at natural $\mathrm{pH} 3.42$ and $j=33.3 \mathrm{~mA} \mathrm{~cm}^{-2}$ were detected by GC-MS. A non-polar Agilent J\&W HP- $5 \mathrm{~ms} \quad 0.25 \mu \mathrm{m}, 30 \mathrm{~m} \times 0.25 \mathrm{~mm}$ (i.d.), column was utilized and NIST05 MS library was used to correlate the mass spectra (Thiam et al., 2018). The generated short-linear aliphatic carboxylic acids were identified and quantified by ion-exclusion HPLC. The above LC fitted with a Bio-Rad Aminex HPX $87 \mathrm{H}, 300 \mathrm{~mm} \times 7.8 \mathrm{~mm}$ (i.d), column at $35^{\circ} \mathrm{C}$ was used, following the procedure reported in an earlier work (Thiam et al., 2018). These chromatograms presented well-defined peaks related to oxalic $\left(t_{\mathrm{r}}=6.9 \mathrm{~min}\right)$ and oxamic $\left(t_{\mathrm{r}}=9.5 \mathrm{~min}\right)$ acids.

\section{Results and discussion}

\subsection{Influence of the anode on the PEF treatment of chloramben in sulfate medium}

A first series of assays was carried out to assess the importance of the anode in PEF process, using either $\mathrm{BDD}, \mathrm{PbO}_{2}, \mathrm{IrO}_{2}$-based or $\mathrm{RuO}_{2}$-based materials. The experiments were performed with $100 \mathrm{~mL}$ of a $1.19 \mathrm{mM}$ herbicide solution (corresponding to $100 \mathrm{mgL}^{-1} \mathrm{TOC}$ ) containing $0.050 \mathrm{M} \mathrm{Na}_{2} \mathrm{SO}_{4}$ and $0.50 \mathrm{mM} \mathrm{Fe}^{2+}$ as catalyst, by applying a $j=100 \mathrm{~mA} \mathrm{~cm}^{-2}$ for $300 \mathrm{~min}$. The natural $\mathrm{pH}$ of the solution (3.42) was not modified, and it only showed a slight decay down to near 3, probably as a result of the formation of acidic by-products (Brillas et al., 2009; Sirés et al., 2014).

The abatement of the herbicide concentration in these trials is presented in Fig. 1a. A fast decay can be observed, achieving total removal in about $15 \mathrm{~min}$, with analogous profiles for all the anodes tested. The exponential concentration decays were analyzed considering kinetic equations related to simple reaction orders, yielding best-fit linear regressions for a pseudo-first-order kinetics (see inset of Fig. 1a). From these correlations, a pseudo-first-order rate constant $\left(k_{1}\right)$ of $0.47 \pm 0.02 \mathrm{~min}^{-1}$, with a squared regression coefficient $\left(R^{2}\right)$ close to 0.995 , was determined regardless of the anode 

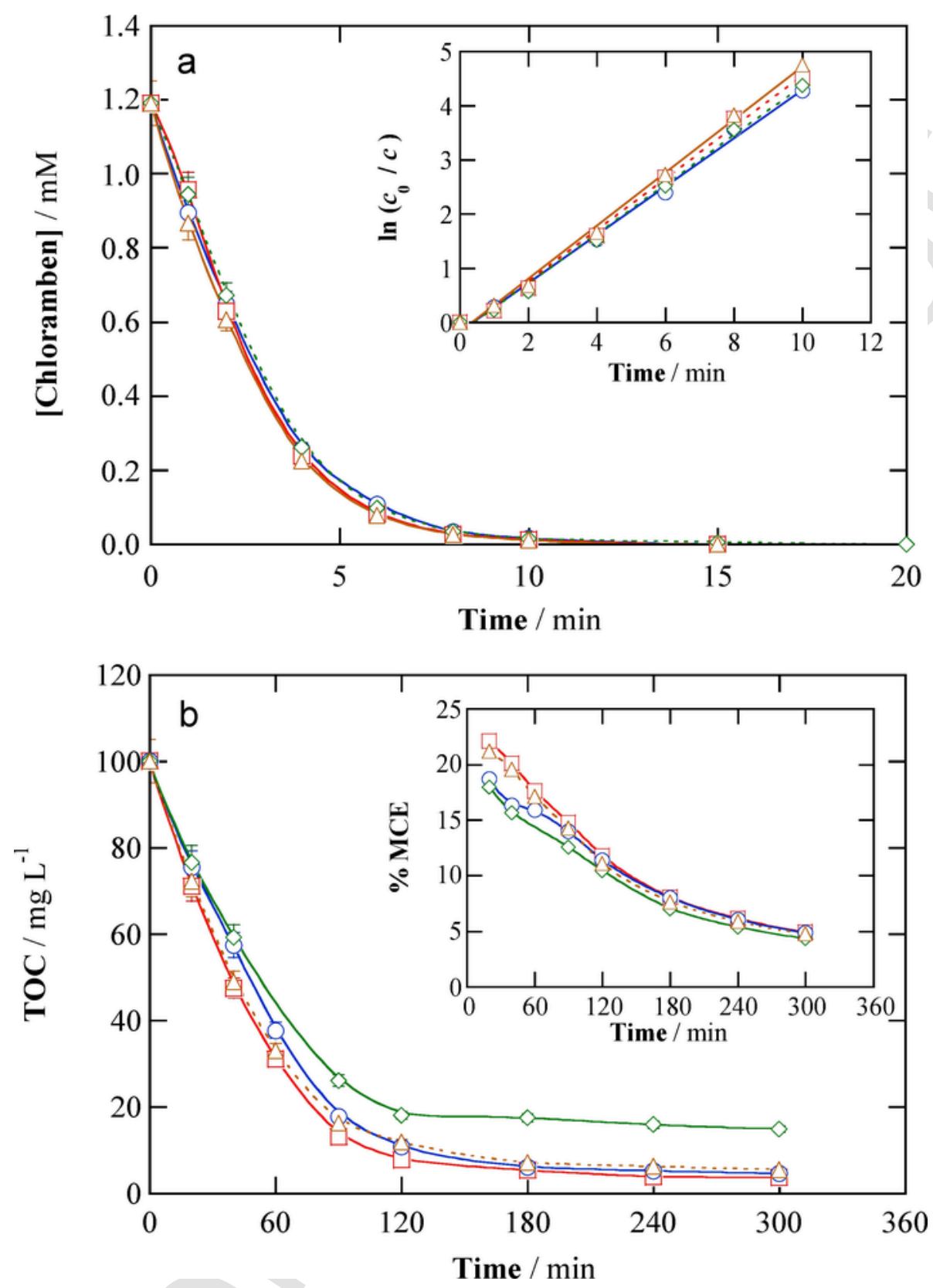

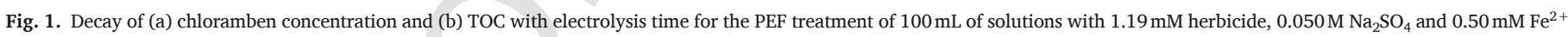

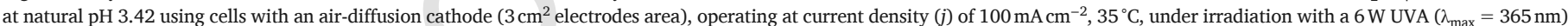

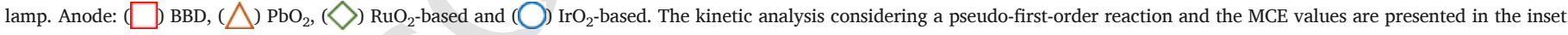
panels of (a) and (b), respectively.

nature. These findings suggest that the pre-eminent oxidizing species reacting with chloramben is ${ }^{\circ} \mathrm{OH}$ generated from Fenton's reaction (1) and enhanced upon occurrence of reaction (3), with minor participation of $\mathrm{M}\left({ }^{\bullet} \mathrm{OH}\right)$ formed at each anode surface from reaction (6). A small and constant quantity of ${ }^{-} \mathrm{OH}$ is then expected to be originated, which accounts for the pseudo-first-order behavior.

More significant influence of the anode material on PEF performance was found from the TOC removal of the same chloramben solutions. Fig. 1b reveals that the BDD anode allowed a slightly faster mineralization than the $\mathrm{PbO}_{2}$ and $\mathrm{IrO}_{2}$-based ones, at least during the first $120 \mathrm{~min}$ of electrolysis, although a similar mineralization with 95\%-96\% TOC abatement was achieved with these three anodes at $300 \mathrm{~min}$. In contrast, the use of a $\mathrm{RuO}_{2}$-based anode caused a deceleration of mineralization, with $82 \%$ TOC removal at $120 \mathrm{~min}$, whereupon the decrease was practically inhibited until a final TOC reduction of $85 \%$ was attained (see Fig. $1 \mathrm{~b}$ ). The initially greater mineralization power of BDD as compared to $\mathrm{PbO}_{2}$ and $\mathrm{IrO}_{2}$-based anodes agrees with the gradually lower oxidation ability of generated $\mathrm{M}\left({ }^{\bullet} \mathrm{OH}\right)$ in the sequence: $\mathrm{BDD}\left({ }^{\bullet} \mathrm{OH}\right)>\mathrm{PbO}_{2}\left({ }^{\bullet} \mathrm{OH}\right) \sim \mathrm{IrO}_{2}\left({ }^{\bullet} \mathrm{OH}\right)>\mathrm{RuO}_{2}($ ${ }^{\circ} \mathrm{OH}$ ) (Martínez-Huitle et al., 2015; Coria et al., 2016; Steter et al., 2018). Nevertheless, our results point to consider that the main oxidant was ${ }^{\circ} \mathrm{OH}$ in the bulk, as also reported for other compounds (Liu et al., 2017, 2018), which acted synergistically with UVA light that promoted the photodegradation of photoactive intermediates. At the end of these experiments, a $\mathrm{NH}_{4}{ }^{+}$concentration of $0.70 \pm 0.05 \mathrm{mM}$ was accumulated in the resulting solutions, related to $59 \pm 4 \%$ of the initial $\mathrm{N}$ content. Neither ni- 
trate nor nitrite were detected, which means that the $-\mathrm{NH}_{2}$ group of chloramben was pre-eminently mineralized to $\mathrm{NH}_{4}{ }^{+}$ion, as proposed in reaction (10). The fact that the content of this ion did not account for all the initial $\mathrm{N}$ suggests the loss of volatile $\mathrm{N}$-containing products such as $\mathrm{N}_{2}$ and $\mathrm{N}_{\mathrm{x}} \mathrm{O}_{\mathrm{y}}$, as proposed for the treatment of other $N$-aromatics by EAOPs (Almeida et al., 2012; Salazar et al., 2012; Thiam et al., 2015, 2018).

From the above results, the MCE values for each experiment were calculated from Eq. (9), as depicted in the inset of Fig. 1b. As can be seen, greater MCE values of about $21 \%-22 \%$ were initially determined in $\mathrm{PEF}$ with the non-active $\mathrm{BDD}$ and $\mathrm{PbO}_{2}$ anodes, meaning that a slightly faster mineralization occurred due to the action of $\operatorname{BDD}\left({ }^{\circ} \mathrm{OH}\right)$ and $\mathrm{PbO}_{2}\left({ }^{\bullet} \mathrm{OH}\right)$. At longer time, when the mineralization was rather controlled by ${ }^{\bullet} \mathrm{OH}$ and UVA radiation, quite similar decay profiles can be observed in all cases, reaching low final values between $4 \%$ and $5 \%$. The continuous fall of MCE can be accounted for by the formation of more persistent intermediates along with the gradual loss of organic matter (Sirés et al., 2014; Martínez-Huitle et al., 2015).

Based on the similar PEF results obtained using the active $\mathrm{IrO}_{2}$-based anode and non-active $\mathrm{BDD}$ and $\mathrm{PbO}_{2}$ ones, subsequent experiments were performed with the former anode in order to clarify its viability by examining the role of the oxidizing species and the effect of experimental variables and ions content in the aqueous matrix.

\subsection{Comparative destruction of chloramben by EAOPs with an $\mathrm{IrO}_{2}$-based anode}

Fig. 2a shows a very slow abatement of the herbicide concentration during the $\mathrm{EO}-\mathrm{H}_{2} \mathrm{O}_{2}$ treatment of $100 \mathrm{~mL}$ of a solution with $1.19 \mathrm{mM}$ chloramben and $0.050 \mathrm{M} \mathrm{Na}_{2} \mathrm{SO}_{4}$ at natural $\mathrm{pH}$ and $j=100 \mathrm{~mA} \mathrm{~cm}^{-2}$, only being reduced by $68 \%$ after $360 \mathrm{~min}$. In contrast, the comparable $\mathrm{EF}$ and PEF processes in the presence of $0.50 \mathrm{mM} \mathrm{Fe}^{2+}$ yielded total removal at 20 and $15 \mathrm{~min}$, respectively. This is an evidence of the very slow degradation of the herbicide with $\operatorname{IrO}_{2}\left({ }^{\bullet} \mathrm{OH}\right)$, the main oxidant in EO- $\mathrm{H}_{2} \mathrm{O}_{2}$, whereas it is very rapidly destroyed by ${ }^{\circ} \mathrm{OH}$ formed from Fenton's reaction (1) in EF. The decay is further accelerated in PEF due to the quicker $\mathrm{Fe}^{2+}$ regeneration from reaction (3). Note that no kinetic equation fitted the concentration decay during the $\mathrm{EO}-\mathrm{H}_{2} \mathrm{O}_{2}$ treatment, suggesting a complex reaction between the herbicide and $\operatorname{IrO}_{2}\left({ }^{\bullet} \mathrm{OH}\right)$. A pseudo-first-order kinetics, however, was obeyed in EF and PEF, with $k_{1}$-values of $0.35 \mathrm{~min}^{-1}\left(R^{2}=9.996\right)$ and $0.44 \mathrm{~min}^{-1}\left(R^{2}=0.994\right)$, respectively.

This behavior was also confirmed from the corresponding TOC removal as depicted in Fig. 2b. A growing oxidation power of the EAOPs can be observed in the sequence: EO- $\mathrm{H}_{2} \mathrm{O}_{2}<\mathrm{EF}<\mathrm{PEF}$. The very low oxidation ability of $\operatorname{IrO}_{2}\left({ }^{\bullet} \mathrm{OH}\right)$ and generated $\mathrm{H}_{2} \mathrm{O}_{2}$ only allowed a poor TOC abatement of $9 \%$ at $300 \mathrm{~min}$ of $\mathrm{EO}-\mathrm{H}_{2} \mathrm{O}_{2}$. The EF process was much more powerful and 55\% TOC removal was achieved at the end. This means that the ${ }^{\bullet} \mathrm{OH}$ amount coming from Fenton's reaction (3) was enough to mineralize many intermediates in the bulk, although a large proportion of by-products could not be removed by this radical. In contrast, the PEF treatment led to $96 \%$ TOC reduction and hence, almost total mineralization is feasible because the incident UVA photons photodegrade those by-products that cannot be destroyed by ${ }^{\bullet} \mathrm{OH}$. This explains the low influence of the anode in the PEF treatment of chloramben.
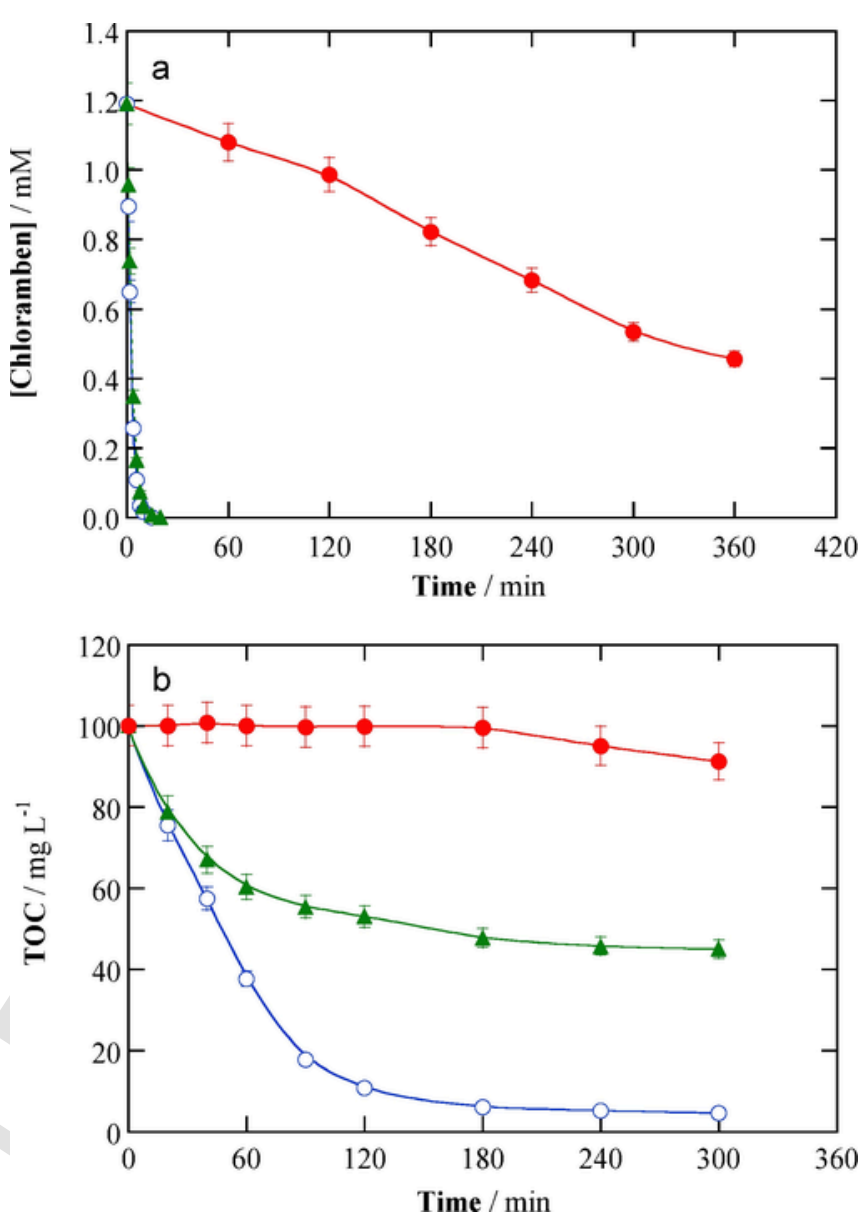

Fig. 2. (a) Herbicide concentration and (b) TOC vs. electrolysis time for the treatment of $100 \mathrm{~mL}$ of $1.19 \mathrm{mM}$ chloramben in $0.050 \mathrm{M} \mathrm{Na}_{2} \mathrm{SO}_{4}$ at natural $\mathrm{pH} 3.42$ using a stirred $\mathrm{IrO}_{2}$-based/air-diffusion cell at $j=100 \mathrm{~mA} \mathrm{~cm}^{-2}$ and $35^{\circ} \mathrm{C}$. Method: (O) $\mathrm{EO}-\mathrm{H}_{2} \mathrm{O}_{2}$, ( ) $\mathrm{EF}$ with $0.50 \mathrm{mM} \mathrm{Fe}^{2+}$ and $(\mathrm{O}) \mathrm{PEF}$ with $0.50 \mathrm{mM} \mathrm{Fe}^{2+}$ and a $6 \mathrm{~W}$ UVA lamp.

\subsection{Effect of experimental parameters and chloride concentration on PEF process}

First, the influence of $j$ between 33.3 and $100 \mathrm{mAcm}^{-2}$ on the performance of PEF treatment of $1.19 \mathrm{mM}$ herbicide in sulfate medium with $0.50 \mathrm{mM} \mathrm{Fe}^{2+}$ at natural $\mathrm{pH}$ was assessed using the $\mathrm{IrO}_{2}$-based/air-diffusion cell. Fig. 3a highlights a very rapid decay of chloramben concentration in all cases, disappearing after 40 min at $33.3 \mathrm{~mA} \mathrm{~cm}^{-2}$ and $15 \mathrm{~min}$ at $100 \mathrm{mAcm}^{-2}$. The enhancement of herbicide removal with raising $j$ can be associated with the concomitant faster generation of • $\mathrm{OH}$ (along with $\mathrm{M}\left({ }^{\bullet} \mathrm{OH}\right)$ ). This is feasible because greater $\mathrm{H}_{2} \mathrm{O}_{2}$ concentration is produced from reaction (5) at higher $j$, which then reacts more rapidly with $\mathrm{Fe}^{2+}$ to accelerate $\cdot \mathrm{OH}$ generation from Fenton's reaction (1) (Brillas et al., 2009; Almeida et al., 2012). From the pseudo-first-order linear correlations shown in the inset, increasing $k_{1}$-values of $0.16 \mathrm{~min}^{-1}\left(R^{2}=0.990\right), 0.33 \mathrm{~min}^{-1}\left(R^{2}=0.995\right)$ and 0.44 $\mathrm{min}^{-1}\left(R^{2}=0.994\right)$ were determined for $33.3,66.7$ and $100 \mathrm{mAcm}^{-2}$, respectively. This evidences a constant ${ }^{\bullet} \mathrm{OH}$ production for all the $j$ values.

Conversely, much smaller differences in TOC decay were found in these trials. Fig. 3b shows a slightly slower mineralization at $j=33.3 \mathrm{mAcm}^{-2}$ up to $120 \mathrm{~min}$ of electrolysis, whereupon TOC reduction was practically inhibited and finally attained $88 \%$. Similar abatements can be observed at 66.7 and $100 \mathrm{mAcm}^{-2}$ up to 

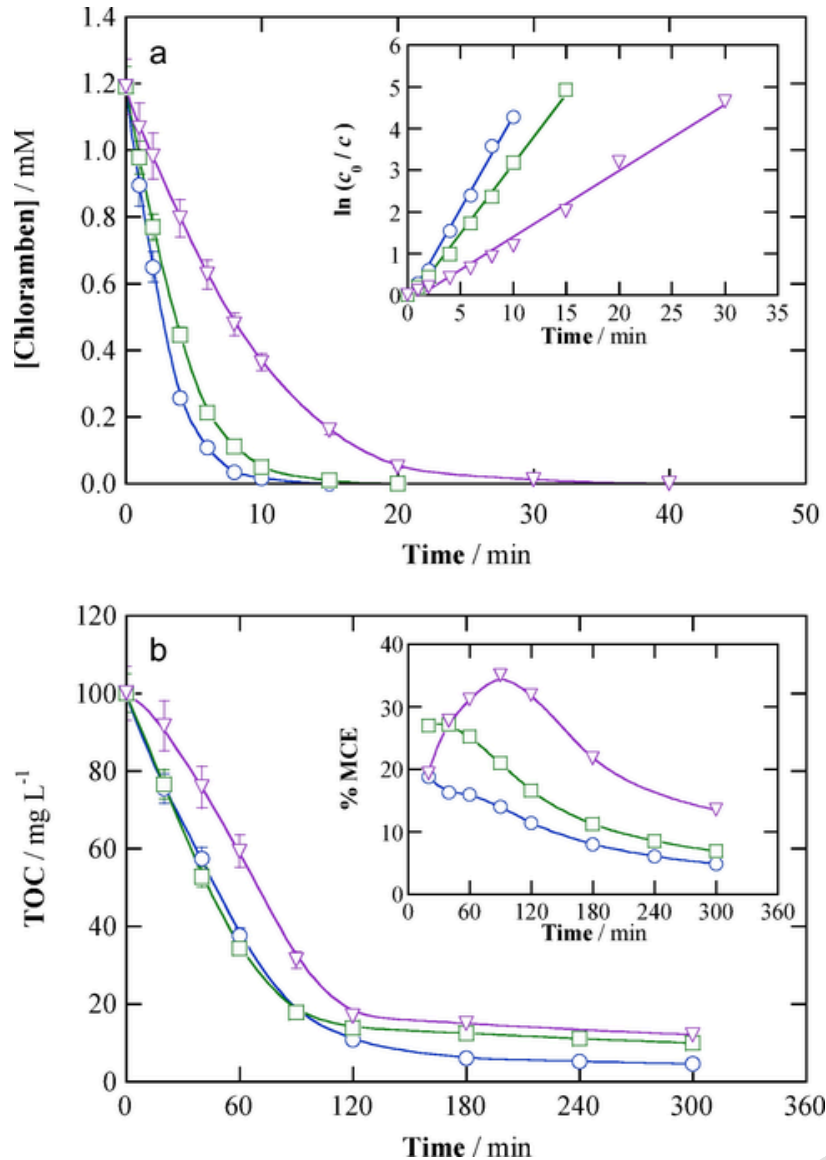

Fig. 3. Effect of current density on the change of (a) chloramben content and (b) TOC with electrolysis time for the PEF treatment of $100 \mathrm{~mL}$ of a $1.19 \mathrm{mM}$ herbicide solution in $0.050 \mathrm{M} \mathrm{Na}_{2} \mathrm{SO}_{4}$ with $0.50 \mathrm{mM} \mathrm{Fe}{ }^{2+}$ at natural $\mathrm{pH} 3.42$ and $35^{\circ} \mathrm{C}$, using a stirred $\mathrm{IrO}_{2}$-based/air-diffusion cell. Current density: (O) $100 \mathrm{~mA} \mathrm{~cm}^{-2}$, ( $66.7 \mathrm{~mA} \mathrm{~cm}^{-2}$ and (V) $33.3 \mathrm{mAcm}^{-2}$. The inset panels show the corresponding kinetic analysis for a pseudo-first-order reaction and MCE variation in (a) and (b), respectively.

approximately $120 \mathrm{~min}$, where TOC was reduced by $86 \%$ and $89 \%$, respectively. Further TOC decays, however, were much poorer, eventually reaching $90 \%$ and $96 \%$. The quick loss of TOC during the first 120 min of PEF treatment at all $j$ tested is due to the fast photolysis of intermediates under UVA irradiation. The predominant role of UVA light minimizes the greater oxidation rate resulting from increase of $j$. At longer time, all photoactive intermediates seem to be already mineralized, and the remaining by-products are very slowly destroyed because they are quite stable against hydroxyl radicals. In PEF, a loss in MCE is expected at higher $j$ since a larger proportion of ${ }^{\bullet} \mathrm{OH}$ in the bulk is consumed by parasitic non-oxidizing reactions, like its dimerization and its attack over $\mathrm{H}_{2} \mathrm{O}_{2}$ (Brillas, 2014; Martínez-Huitle et al., 2015). This behavior can be confirmed in the inset of Fig. $3 \mathrm{~b}$ at long electrolysis time, with decreasing final MCE values of $13.5 \%, 6.9 \%$ and $4.9 \%$ at raising $j$ of 33.3, 66.7 and $100 \mathrm{mAcm}^{-2}$. These results inform about the convenience of using low $j$ values, in order to operate with lower energy consumptions.

The influence of the herbicide concentration on PEF process was studied under the same conditions by applying the lowest $j=33.3 \mathrm{~mA} \mathrm{~cm}^{-2}$ to better elucidate the role of oxidizing agents. As can be seen in Fig. 4a, the normalized concentration decay was progressively decelerated as the herbicide content rose from 0.59 to $2.38 \mathrm{mM}$, disappearing at 30 and $120 \mathrm{~min}$ of the treatment, respectively. This trend seems logical because analogous quantities of
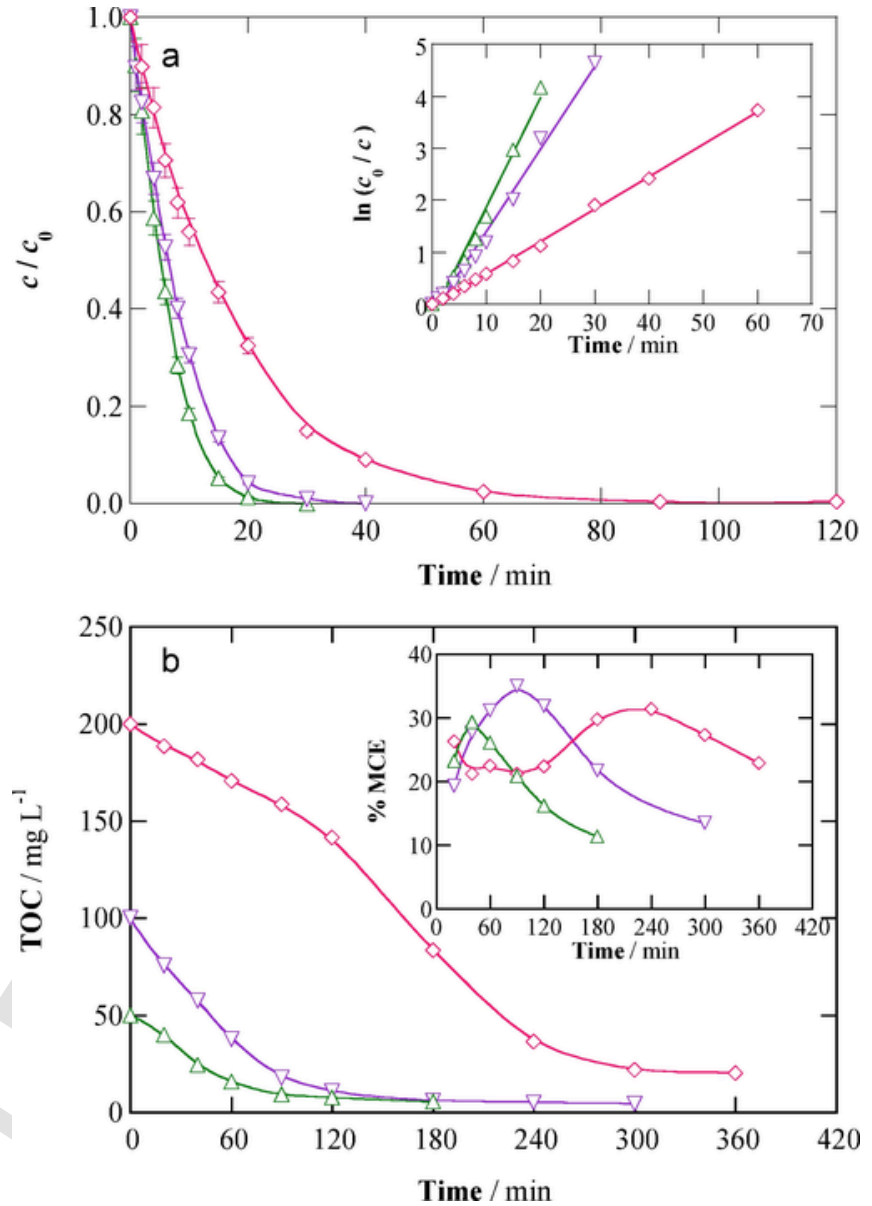

Fig. 4. Effect of herbicide concentration on (a) normalized chloramben content and (b) TOC abatement for the PEF degradation of $100 \mathrm{~mL}$ of herbicide solutions in $0.05 \mathrm{M}$ $\mathrm{Na}_{2} \mathrm{SO}_{4}$ with $0.50 \mathrm{mM} \mathrm{Fe}^{2+}$ of natural $\mathrm{pH}$ using a stirred $\mathrm{IrO}_{2}$-based/air-diffusion cell

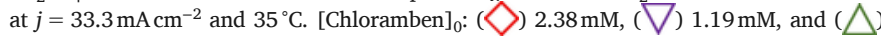
$0.59 \mathrm{mM}$. The kinetic analysis for the herbicide removal and the change of MCE are presented in the inset panels of (a) and (b), respectively.

hydroxyl radicals were originated in these trials at a fixed $j$. This leads to a slower slope of the straight lines accounting for a pseudo-first-order kinetics (see the inset of Fig. 4a), with decreasing $k_{1}$-values of $0.21 \mathrm{~min}^{-1}$ $\left(R^{2}=0.987\right), 0.16 \mathrm{~min}^{-1}\left(R^{2}=0.990\right)$ and $0.062 \mathrm{~min}^{-1}\left(R^{2}=0.998\right)$ at $0.59,1.19$ and $2.38 \mathrm{mM}$ chloramben, respectively. Hence, the herbicide abatement did not follow a true pseudo-first-order reaction, meaning that under each experimental condition a different steady ${ }^{\circ} \mathrm{OH}$ concentration is formed.

Regarding the corresponding TOC removals, an S-shape profile was obtained at the highest herbicide content. In this case, Fig. 4b shows a slow mineralization up to $120 \mathrm{~min}$, followed by a very fast TOC decay until the end of the trial. This behavior suggests a gradual generation of photoactive intermediates from ${ }^{*} \mathrm{OH}$ oxidation, which are very effectively photodegraded by UVA light between 120 and $300 \mathrm{~min}$. In contrast, a progressive TOC abatement can be observed in Fig. 4b starting at 1.19 and $0.59 \mathrm{mM}$, suggesting a quicker formation of photoactive organics that are then rapidly photodegraded. TOC removal was $88-90 \%$ at the end of all these trials, regardless the initial herbicide content, which can be explained by the production of a similar proportion of persistent by-products (10-12\% of the initial C) to oxidation/photolysis. The MCE values in these assays agree with the TOC profiles. The inset of Fig. 4b highlights maximum MCE values of $29.3 \%$ at $40 \mathrm{~min}$, $35.1 \%$ at $90 \mathrm{~min}$ and $31.3 \%$ at $240 \mathrm{~min}$ at $0.59,1.19$ and $2.38 \mathrm{mM}$, 
respectively. This corresponds to the transition between increasing and decreasing mineralization rates, the latter being due to the progressive loss of organic matter and the larger accumulation of refractory by-products. The shift of the maximal to longer time with increasing herbicide content confirms the slower generation of photoactive by-products, as stated above. Note that, when treating highly concentrated solutions, the MCE values may rose at long time (e.g., $180 \mathrm{~min}$ ), suggesting a larger availability of ${ }^{\bullet} \mathrm{OH}$ that arises from the deceleration of its parasitic reactions (Brillas et al., 2009; Brillas, 2014; Sirés et al., 2014; Martínez-Huitle et al., 2015).

Since urban and industrial wastewater usually contain a large amount of $\mathrm{Cl}^{-}$ion, apart from $\mathrm{SO}_{4}{ }^{2-}$ ion, the effect of the former ion on PEF treatment of $1.19 \mathrm{mM}$ chloramben solutions at natural $\mathrm{pH}$ was investigated at $j=33.3 \mathrm{~mA} \mathrm{~cm}^{-2}$. Fig. 5 a reveals that using $0.035 \mathrm{M}$ $\mathrm{NaCl}+0.025 \mathrm{M} \mathrm{Na}_{2} \mathrm{SO}_{4}$ (same conductivity as $0.050 \mathrm{M} \mathrm{Na}_{2} \mathrm{SO}_{4}$, i.e., $5.8 \mathrm{mScm}^{-1}$ ) and $0.011 \mathrm{M} \mathrm{NaCl}+0.0015 \mathrm{M} \mathrm{Na}_{2} \mathrm{SO}_{4}$ (similar conductivity, near $3 \mathrm{mScm}^{-1}$, as compared to real wastewater) as synthetic aqueous matrices, complete removal of the herbicide was reached after $40 \mathrm{~min}$, the same time needed with $0.050 \mathrm{M} \mathrm{Na}_{2} \mathrm{SO}_{4}$. Nevertheless, a slower decay occurred with $0.035 \mathrm{M} \mathrm{NaCl}$, which was more significant when the $\mathrm{Cl}^{-}$content dropped to $0.011 \mathrm{M}$. In these media, the production of high amounts
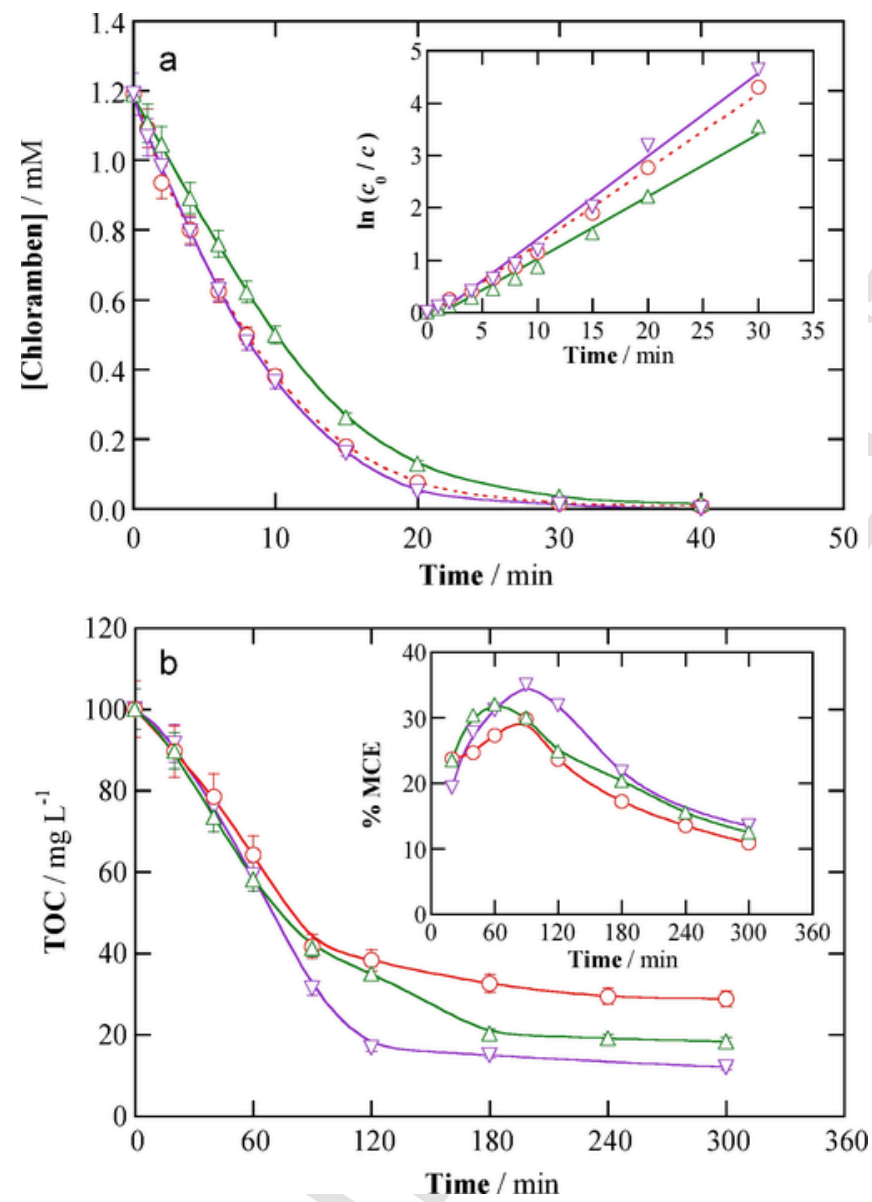

Fig. 5. Influence of chloride content on the variation of (a) chloramben concentration and (b) TOC with electrolysis time for the PEF treatment of $100 \mathrm{~mL}$ of $1.19 \mathrm{mM}$ herbicide solutions with $0.50 \mathrm{mM} \mathrm{Fe}{ }^{2+}$ at $\mathrm{pH} 3.4$ using a stirred $\mathrm{IrO}_{2}$-based/air-diffusion cell at $j=33.3 \mathrm{~mA} \mathrm{~cm}^{-2}$ and $35^{\circ} \mathrm{C}$. Electrolyte composition: ( $\left.\nabla\right) 0.050 \mathrm{M} \mathrm{Na}_{2} \mathrm{SO}_{4},(\mathrm{O}) 0.035 \mathrm{M}$ $\mathrm{NaCl}+0.025 \mathrm{M} \mathrm{Na}_{2} \mathrm{SO}_{4}$ and $(\triangle) 0.011 \mathrm{M} \mathrm{NaCl}+0.0015 \mathrm{M} \mathrm{Na}_{2} \mathrm{SO}_{4}$. The inset panels of (a) and (b) depict the corresponding pseudo-first-order kinetic analysis and the MCE values, respectively. of active chlorine $\left(\mathrm{Cl}_{2} / \mathrm{HClO}\right)$ from $\mathrm{Cl}^{-}$oxidation at the $\mathrm{IrO}_{2}$-based anode by reactions (7) and (8) is expected (Coria et al., 2016; Steter et al., 2016). The profiles of Fig. 5a suggest a competition between both, active chlorine and ${ }^{\bullet} \mathrm{OH}$, to attack the herbicide in the bulk. The corresponding $k_{1}$-values determined from the linear regressions shown in the inset panel of Fig. 5a rose from $0.12 \mathrm{~min}^{-1}\left(R^{2}=0.989\right)$ in the presence of $0.011 \mathrm{M} \mathrm{NaCl}$ to $0.14 \mathrm{~min}^{-1}\left(R^{2}=0.993\right)$ using $0.035 \mathrm{M} \mathrm{NaCl}$, a value slightly smaller than $0.16 \mathrm{~min}^{-1}$ found in the $\mathrm{Cl}^{-}$-free medium. The fact that a pseudo-first-order kinetics was always found means that a steady concentration of all oxidizing agents was always formed. As presented in Fig. $5 \mathrm{~b}$, the TOC decays determined during these experiments were quite similar up to $60 \mathrm{~min}$ of electrolysis, reaching about $40 \%$ mineralization. At longer time, smaller amounts of TOC were removed as the solution contained more $\mathrm{Cl}^{-}$. Thus, TOC was reduced by $88 \%$ in $0.050 \mathrm{M}$ $\mathrm{Na}_{2} \mathrm{SO}_{4}, 82 \%$ in the solution with $0.011 \mathrm{M} \mathrm{NaCl}$ and $72 \%$ in that with $0.035 \mathrm{M} \mathrm{NaCl}$. This is also confirmed from the $13.5 \%, 12.5 \%$ and $10.9 \%$ MCE values finally reached (see inset of Fig. 5b). This tendency can be accounted for the fast photodegradation of non-chlorinated photoactive products in the two latter matrices, with larger formation of persistent chloroderivatives as the medium contains more $\mathrm{Cl}^{-}$. Consequently, the presence of excessively high concentrations of the latter ion may become detrimental for chloramben mineralization.

\subsection{Identification of aromatic intermediates and final carboxylic acids}

Fig. 6 shows a general reaction sequence for the primary degradation of chloramben. It includes the aromatic products detected by GC-MS when $1.19 \mathrm{mM}$ chloramben solutions in $0.050 \mathrm{M} \mathrm{Na}_{2} \mathrm{SO}_{4}$ or $0.011 \mathrm{M}$ $\mathrm{NaCl}+0.0015 \mathrm{M} \mathrm{Na}_{2} \mathrm{SO}_{4}$ were treated for short times under PEF conditions with an $\mathrm{IrO}_{2}$-based/air-diffusion cell at $j=33.3 \mathrm{~mA} \mathrm{~cm}^{-2}$. This pathway presupposes than in sulfate medium, the main oxidizing agent is ${ }^{\circ} \mathrm{OH}$ in the bulk, whereas in chlorinated matrix, active chlorine $\left(\mathrm{Cl}_{2} / \mathrm{HClO}\right)$ acts synergistically.

Upon ${ }^{\circ} \mathrm{OH}$-mediated oxidation in $0.050 \mathrm{M} \mathrm{Na}_{2} \mathrm{SO}_{4}$, chloramben was decarboxylated to yield 2,5-dichlorobenzamine, deaminated to 2,5-dichlorobenzoic acid and dechlorinated to 3-amino-5-chlorobenzoic acid. The former compound was further hydroxylated to 3-amino-2,5-dichlorophenol, which was subsequently deaminated to 2,5-dichloro-1,3-benzenediol. The other two compounds were in turn either dechlorinated or deaminated to yield 3-chlorobenzoic acid, followed by dechlorination to form benzoic acid. It is noteworthy that 3-amino-5-chlorobenzoic, 2,5-dichlorobenzoic and benzoic acids have also been reported as by-products during the degradation of chloramben by $\mathrm{TiO}_{2} / \mathrm{H}_{2} \mathrm{O}_{2} /$ UVC (Bianco Prevot et al., 1999).

In the presence of chloride, the oxidation with ${ }^{\circ} \mathrm{OH}$ yielded 2,5-dichlorobenzamine, which was deaminated and hydroxylated to 2,5-dichloro-1,3-benzenediol. Fig. 6 highlights the consecutive chlorination of the latter compound with active chlorine leading to 2,4,5-trichloro-1,3-benzenediol and 2,3,4,5-tetrachlorophenol. On the other hand, direct chlorination + hydroxylation of chloramben yielded 3,5,6-trichlorosalicylic acid with loss of $\mathrm{NH}_{4}{ }^{+}$ion. The detection of these intermediates corroborates the generation of persistent chloroderivatives that inhibit the total mineralization of the herbicide in chlorinated matrices.

Further evolution of the above aromatic intermediates involves the cleavage of the benzene moiety with the expected formation of final short-linear aliphatic carboxylic acids (Almeida et al., 2012; Thiam et al., 2015, 2018; Steter et al., 2016, 2018). This was confirmed for chloramben by analyzing the $1.19 \mathrm{mM}$ solutions treated under the EF and PEF conditions described in Fig. 2. Two 


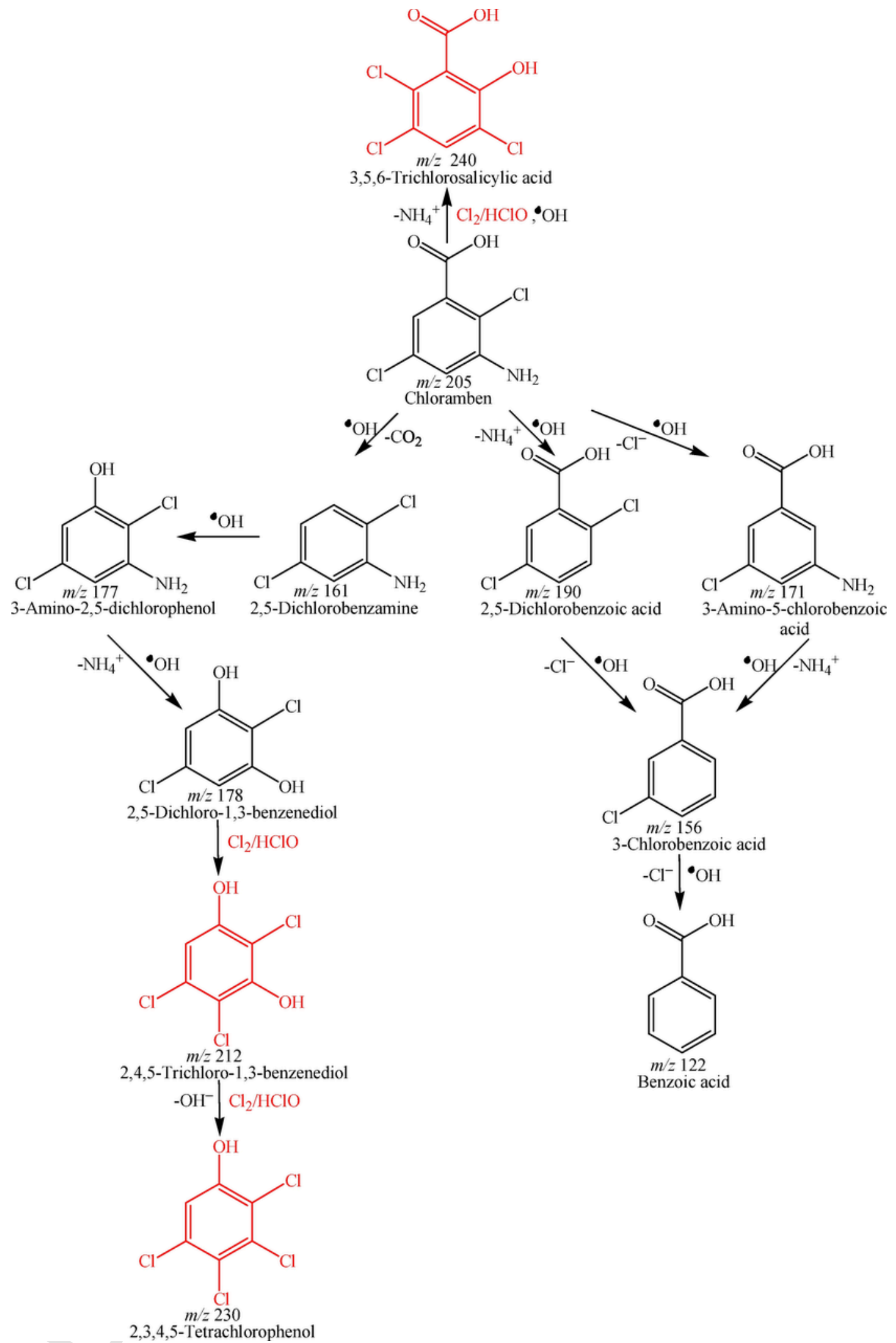

Fig. 6. Reaction sequence for initial chloramben degradation by PEF in sulfate and/or chloride medium.

final acids, oxalic and oxamic, which are directly mineralized to $\mathrm{CO}_{2}$, were detected. Fig. 7a highlights that oxalic acid was accumulated up to $111 \mathrm{mgL}^{-1}$ after $60-90 \mathrm{~min}$ of $\mathrm{EF}$, whereupon its con- tent remained stable. The refractory Fe(III)-oxalate complexes formed in the bulk allow explaining this behavior (Almeida et al., 2012). The fast photodecarboxylation of these complexes under 


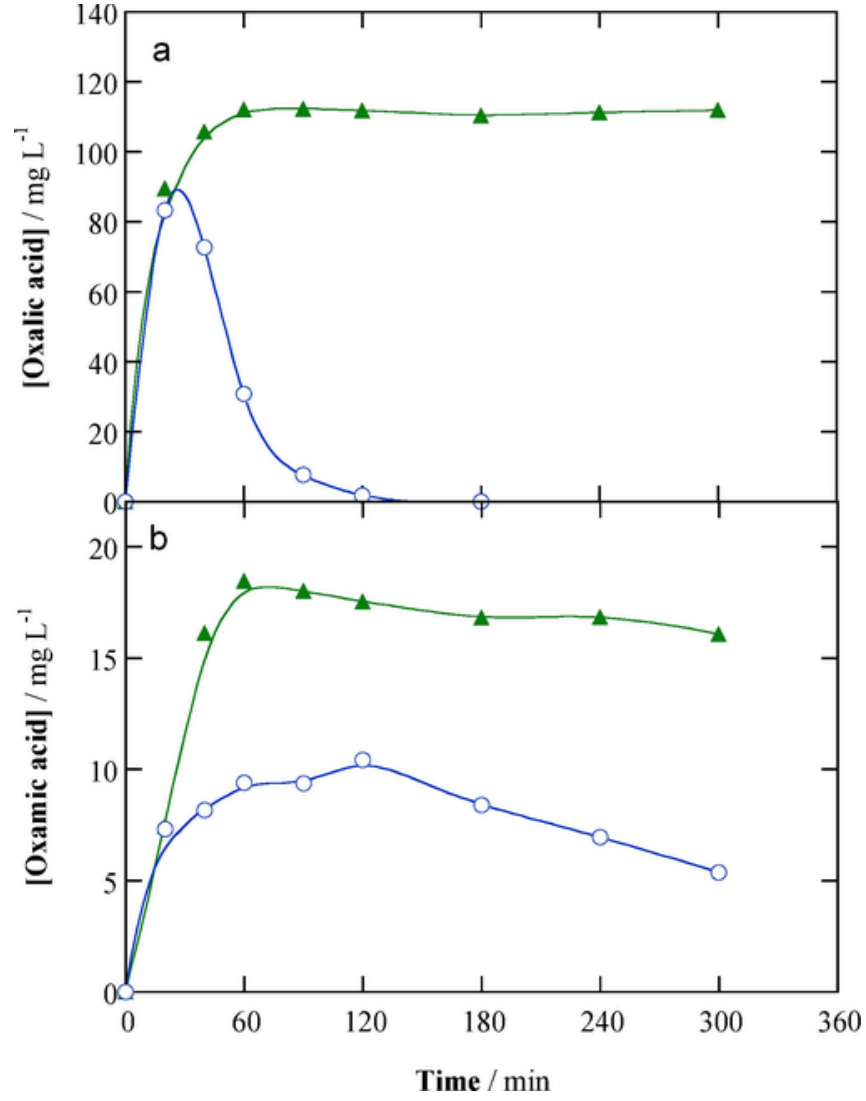

Fig. 7. Evolution of the concentration of (a) oxalic and (b) oxamic acids detected by ion-exclusion HPLC under the same conditions of the trials shown in Fig. 2 for ( $) \mathrm{EF}$ and $(\bigcirc)$ PEF.

UVA light irradiation via reaction (2) justifies its disappearance after 120-180 min of PEF (see Fig. 7a). In the case of oxamic acid, Fig. 7b reveals the accumulation of $16-18 \mathrm{mg} \mathrm{L}^{-1}$ after $60-90$ of EF, whereas in $\mathrm{PEF}$, it drops from $10.4 \mathrm{mg} \mathrm{L}^{-1}$ at $120 \mathrm{~min}$ to $5.4 \mathrm{mg} \mathrm{L}^{-1}$ at $300 \mathrm{~min}$, indicating a slower photolysis of its Fe(III) complexes. A mass balance at the end of these EF and PEF treatments shows that the content of both carboxylic acids corresponds to 33.90 and $1.45 \mathrm{mg} \mathrm{L}^{-1}$ of TOC, respectively, related to a $75.3 \%$ and $32.2 \%$ of the organic matter present in the treated solutions (see Fig. 2b). These results confirm that total mineralization is prevented by the formation of other by-products that are hard to degrade by ${ }^{\bullet} \mathrm{OH}$ and UVA radiation. Moreover, the great amount of oxalic acid formed explains the high effectiveness of PEF, which allows the quick photodegradation of its Fe(III) complexes, not being feasible in EF.

\subsection{PEF treatment of chloramben spiked into urban wastewater}

The study of the PEF treatment of chloramben was extended to urban wastewater as reaction matrix, which contains $\mathrm{Cl}^{-}$and $\mathrm{SO}_{4}{ }^{2-}$ ions as well as NOM (mainly composed by humic and fulvic acids). Preliminary treatment of raw wastewater conditioned at $\mathrm{pH} 3.4$, in the presence of $0.50 \mathrm{mM} \mathrm{Fe}^{2+}$, using a BDD or $\mathrm{IrO}_{2}$-based anode at $j=33.3 \mathrm{mAcm}^{-2}$ showed total removal of initial TOC $\left(15 \mathrm{mg} \mathrm{L}^{-1}\right)$ in $300 \mathrm{~min}$.

Fig. 8a presents the similar decay found from $1.19 \mathrm{mM}$ herbicide spiked into urban wastewater under the above conditions using a BDD or $\mathrm{IrO}_{2}$-based anode. It disappeared in $40 \mathrm{~min}$, i.e., the same time as that required in $0.050 \mathrm{M} \mathrm{Na} \mathrm{Na}_{4}$ and chlorinated ma-
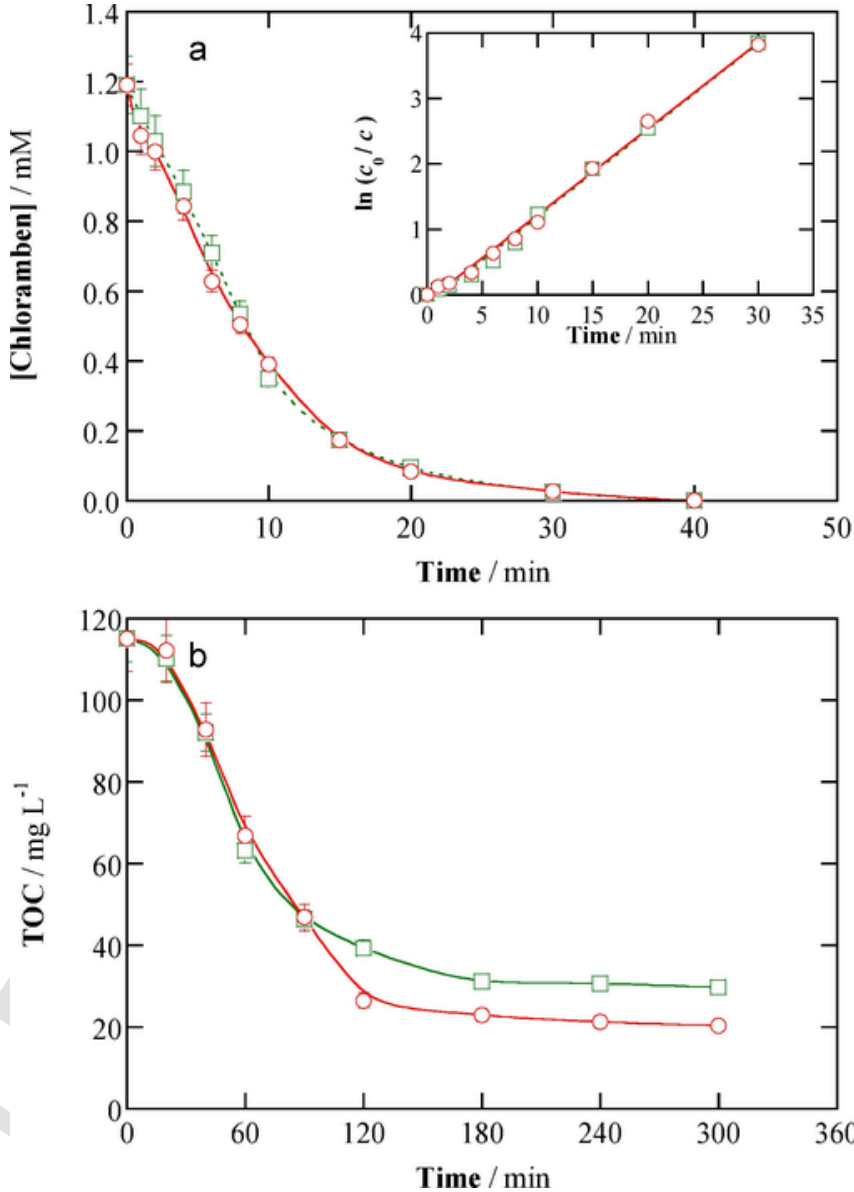

Fig. 8. Change of (a) herbicide concentration and (b) TOC with electrolysis time for PEF treatment of $100 \mathrm{~mL}$ of urban wastewater containing $1.19 \mathrm{mM}$ chloramben and $0.50 \mathrm{mM}$ $\mathrm{Fe}^{2+}$ at pH 3.4 using cells with an air-diffusion cathode and a $(\mathrm{O}) \mathrm{BBD}$ or $(\square) \mathrm{IrO}_{2}$-based anode, operating at $j=33.3 \mathrm{~mA} \mathrm{~cm}^{-2}$ and $35^{\circ} \mathrm{C}$. In (a), the inset panel shows the kinetic analysis assuming a pseudo-first-order reaction.

trices (see Fig. 5a). The inset panel shows the good fit to pseudo-first-order kinetics determined for the concentration decay, yielding the same $k_{1}$-value of $0.13 \mathrm{~min}^{-1}$ with $R^{2}=0.995$ for each anode. This is slightly lower than $0.14-0.16 \mathrm{~min}^{-1}$ obtained in $0.050 \mathrm{M} \mathrm{Na}_{2} \mathrm{SO}_{4}$ and $0.035 \mathrm{M}$ $\mathrm{NaCl}+0.025 \mathrm{M} \mathrm{Na}_{2} \mathrm{SO}_{4}$, meaning that ${ }^{\circ} \mathrm{OH}$ and active chlorine are partially consumed by NOM in urban wastewater.

Fig. 8b evidences a similar decay rate of the initial TOC $\left(115 \mathrm{mg} \mathrm{L}^{-1}\right)$ regardless of the anode used, attaining $60 \%$ abatement during the first 90 min of PEF treatment. At longer time, TOC dropped slowly with 74\% reduction using an $\mathrm{IrO}_{2}$-based anode and much rapidly (82\% decay) with BDD up to about $180 \mathrm{~min}$, whereupon it remained practically constant. The final TOC in the former case was $30 \mathrm{mg} \mathrm{L}^{-1}$, a value quite analogous to $28 \mathrm{mg} \mathrm{L}^{-1}$ remaining after the treatment in $0.035 \mathrm{M} \mathrm{NaCl}$ $+0.025 \mathrm{M} \mathrm{Na}_{2} \mathrm{SO}_{4}$ (see Fig. 5b). This can be related to a large formation of stable chloroderivatives, probably coming from the reaction of oxidation products or some components of NOM, which are responsible for the partial mineralization. The superior oxidation power of BDD can be ascribed to the partial removal of such persistent by-products with the powerful $\mathrm{BDD}\left({ }^{\bullet} \mathrm{OH}\right)$. Nevertheless, the $\mathrm{IrO}_{2}$-based anode is an excellent alternative to destroy most by-products of chloramben in urban wastewater by PEF. Note that the present PEF results are better than $64 \%$ TOC removal reported in earlier work considering a similar treatment of $50 \mathrm{mg} \mathrm{L}^{-1}$ of TOC of pesticide 
carbofuran spiked into urban wastewater with a $\mathrm{RuO}_{2}$-based/air-diffusion cell at $j=50 \mathrm{mAcm}^{-2}$ (Thiam et al., 2018).

\section{Conclusions}

It has been shown that chloramben is degraded at similar rate either in synthetic media with sulfate and/or chloride ions, or urban wastewater, at $\mathrm{pH}$ near 3 . Overall, the anode nature played a minor role. This is related to the pre-eminent degradation by ${ }^{\bullet} \mathrm{OH}$ formed in the bulk and UVA irradiation. The presence of $\mathrm{Cl}^{-}$decelerated the herbicide removal because of its slower reaction with active chlorine. The viability of an $\mathrm{IrO}_{2}$-based DSA ${ }^{\circledR}$ in PEF was confirmed from the $96 \%$ TOC reduction achieved in $0.050 \mathrm{M} \mathrm{Na}_{2} \mathrm{SO}_{4}$. This large mineralization was obtained thanks to the formation of photoactive intermediates, like $\mathrm{Fe}(\mathrm{III})$-carboxylate complexes, upon ${ }^{\bullet} \mathrm{OH}$ attack, being further photograded by UVA light. The generation of persistent chloroderivatives in chlorinated media inhibited the mineralization process. These by-products were more effectively destroyed by BDD in urban wastewater, although an acceptable performance was obtained with the $\mathrm{IrO}_{2}$-based anode. A general pathway for the herbicide mineralization has been proposed from the aromatics identified in the presence of sulfate and chloride.

\section{Acknowledgements}

The authors acknowledge financial support from project CTQ2016-78616-R (AEI/FEDER, EU) and FONDECYT project 3160753 (CONICYT, Chile).

\section{References}

Almeida, L.C., Garcia-Segura, S., Arias, C., Bocchi, N., Brillas, E., 2012. Electrochemical mineralization of the azo dye Acid Red 29 (Chromotrope 2R) by photoelectro-Fenton process. Chemosphere 89, 751-758.

Antonopoulou, M., Evgenidou, E., Lambropoulou, D., Konstantinou, I., 2014. A review on advanced oxidation processes for the removal of taste and odor compounds from aqueous media. Water Res. 53, 215-234.

Assumpção, M.H.M.T., Moraes, A., De Souza, R.F.B., Reis, R.M., Rocha, R.M., Gaubeur, I., Calegaro, M.L., Hammer, P., Lanza, M.R.V., Santos, M.C., 2013. Degradation of dipyrone via advanced oxidation processes using a cerium nanostructured electrocatalyst material. Appl. Catal. A Gen. 462-463, 256-261.

Bianco Prevot, A., Vincenti, M., Bianciotto, A., Pramauro, E., 1999. Photocatalytic and photolytic transformation of chloramben in aqueous solutions. Appl. Catal. B Environ. 22, 149-158.

Brillas, E., 2014. A review on the degradation of organic pollutants in waters by UV photoelectro-Fenton and solar photoelectro-Fenton. J. Braz. Chem. Soc. 25, 393-417.

Brillas, E., Sirés, I., Oturan, M.A., 2009. Electro-Fenton process and related electrochemical technologies based on Fenton's reaction chemistry. Chem. Rev. 109, 6570-6631.

Coria, G., Sirés, I., Brillas, E., Nava, J.L., 2016. Influence of the anode material on the degradation of naproxen by Fenton-based electrochemical processes. Chem. Eng. J. $304,817-825$.

Cruz-González, K., Torres-López, O., García-León, A., Brillas, E., Hernández-Ramírez, A., Peralta-Hernández, J.M., 2012. Optimization of electro-Fenton/BDD process for decolorization of a model azo dye wastewater by means of response surface methodology. Desalination 286, 63-68.

Cruz-González, K., Torres-López, O., García-León, A., Guzmán-Mar, J.L., Reyes, L.H., Hernández-Ramírez, A., Peralta-Hernández, J.M., 2010. Determination of optimum operating parameters for Acid Yellow 36 decolorization by electro-Fenton process using BDD cathode. Chem. Eng. J. 160, 199-206.

Dirany, A., Sirés, I., Oturan, N., Özcan, A., Oturan, M.A., 2012. Electrochemical treatment of the antibiotic sulfachloropyridazine: kinetics, reaction pathways, and toxicity evolution. Environ. Sci. Technol. 46, 4074-4082.

Dominguez, C.M., Oturan, N., Romero, A., Santos, A., Oturan, M.A., 2018. Optimization of electro-Fenton process for effective degradation of organochlorine pesticide lindane. Catal. Today https://doi.org/10.1016/j.cattod.2017.10. 028.

El-Ghenymy, A., Rodríguez, R.M., Brillas, E., Oturan, N., Oturan, M.A., 2014. Electro-Fenton degradation of the antibiotic sulfanilamide with $\mathrm{Pt} /$ carbon-felt and $\mathrm{BDD} / \mathrm{car}$ bon-felt cells. Kinetics, reaction intermediates, and toxicity assessment. Environ. Sci. Pollut. Res. 21, 8368-8378.

Fernández-Castro, P., Vallejo, M., San Román, M.F., Ortiz, I., 2015. Insight on the fundamentals of advanced oxidation processes. Role and review of the determination methods of reactive oxygen species. J. Chem. Technol. Biotechnol. 90, 796-820.

Galia, A., Lanzalaco, S., Sabatino, M.A., Dispenza, C., Scialdone, O., Sirés, I., 2016. Crosslinking of poly(vinylpyrrolidone) activated by electrogenerated hydroxyl radicals: a first step towards a simple and cheap synthetic route of nanogel vectors. Electrochem. Commun. 62, 64-68.

Guinea, E., Brillas, E., Centellas, F., Cañizares, P., Rodrigo, M.A., Sáez, C., 2009. Oxidation of enrofloxacin with conductive-diamond electrochemical oxidation, ozonation and Fenton oxidation. A comparison. Water Res. 43, 2131-2138.

Johnson, G.J., Bullen, L.A., bin Mohd Akil, M.R., 2017. Review on emerging pollutants and advanced oxidation processes. Int. J. Adv. Res. 5, 2315-2324.

Khataee, A., Akbarpour, A., Vahi, B., 2014. Photoassisted electrochemical degradation of an azo dye using $\mathrm{Ti} / \mathrm{RuO}_{2}$ anode and carbon nanotubes containing gas-diffusion cathode. J. Taiwan Inst. Chem. Eng. 45, 930-936.

Khataee, A., Khataee, A., Fathinia, M., Vahid, B., Joo, S.W., 2013. Kinetic modeling of photoassisted-electrochemical process for degradation of an azo dye using boron-doped diamond anode and cathode with carbon nanotubes. J. Ind. Eng. Chem. 19, 1890-1894.

Lanzalaco, S., Sirés, I., Sabatino, M.A., Dispenza, C., Scialdone, O., Galia, A., 2017. Synthesis of polymer nanogels by electro-Fenton process: investigation of the effect of main operation parameters. Electrochim. Acta 246, 812-822.

Liu, X., Yang, D., Zhou, Y., Zhang, J., Luo, L., Meng, S., Chen, S., Tan, M., Li, Z., Tang, L., 2017. Electrocatalytic properties of N-doped graphite felt in electro-Fenton process and degradation mechanism of levofloxacin. Chemosphere 182, 306-315.

Liu, X., Zhou, Y., Zhan, J., Luo, L., Yang, Y., Huang, H., Peng, H., Tang, L., Mu, Y., 2018. Insight into electro-Fenton and photo-Fenton for the degradation of antibiotics: mechanism study and research gaps. Chem. Eng. J. 347, 379-397.

Martínez-Huitle, C.A., Rodrigo, M.A., Sirés, I., Scialdone, O., 2015. Single and coupled electrochemical processes and reactors for the abatement of organic water pollutants: a critical review. Chem. Rev. 115, 13362-13407.

Matavos-Aramyan, S., Moussavi, M., 2017. Advances in Fenton and Fenton based oxidation processes for industrial effluent contaminants control-A review. Int. J. Environ. Sci. Nat. Res. 2, 555594

Mir, N.A., Haque, M.M., Khan, A., Umar, K., Muneer, M., Vijayalakshmi, S., 2012. Semiconductor mediated photocatalysed reaction of two selected organic compounds in aqueous suspensions of titanium dioxide. J. Adv. Oxid. Technol. 15, 380-391.

Misra, B., Graebing, P.W., Chib, J.S., 1997. Photodegradation of chloramben on a soil surface: a laboratory-controlled study. J. Agric. Food Chem. 45, 1464-1467.

Moreira, F.C., Boaventura, R.A.R., Brillas, E., Vilar, V.J.P., 2017. Electrochemical advanced oxidation processes: a review on their application to synthetic and real wastewaters. Appl. Catal. B Environ. 202, 217-261.

Oturan, M.A., Aaron, J.-J., 2014. Advanced oxidation processes in water/wastewater treatment: principles and applications. A review. Crit. Rev. Environ. Sci. Technol. 44, 2577-2641.

Pignatello, J.J., Liu, D., Huston, P., 1999. Evidence for an additional oxidant in the photoassisted Fenton reaction. Environ. Sci. Technol. 33, 1832-1839.

Pignatello, J.J., Oliveros, E., MacKay, A., 2006. Advanced oxidation processes for organic contaminant destruction based on the Fenton reaction and related chemistry. Crit Rev. Environ. Sci. Technol. 36, 1-84.

Ponnusami, B., Muthukumar, K., 2014. A review on Fenton and improvements to the Fenton process for wastewater treatment. J. Environ. Chem. Eng. 2, 557-572

Rahim Pouran, S., Abdul Aziz, A.R., Wan Daud, W.M.A., 2015. Review on the main advances in photo-Fenton oxidation system for recalcitrant wastewaters. J. Ind. Eng. Chem. 21, 53-69.

Recio, F.J., Herrasti, P., Sirés, I., Kulak, A.N., Bavykin, D.V., Ponce-de-León, C., Walsh, F.C., 2011. The preparation of $\mathrm{PbO}_{2}$ coatings on reticulated vitreous carbon for the electro-oxidation of organic pollutants. Electrochim. Acta 56, 5158-5165.

Salazar, R., Brillas, E., Sirés, I., 2012. Finding the best $\mathrm{Fe}^{2+} / \mathrm{Cu}^{2+}$ combination for the solar photoelectro-Fenton treatment of simulated wastewater containing the industrial textile dye Disperse Blue 3. Appl. Catal. B Environ. 115-116, 107-116. 
Seibert, D., Diel, T., Welter, J.B., de Souza, A.L., Módenes, A.N., Espinoza-Quiñones, F.R., Borba, F.H., 2017. Performance of photo-Fenton process mediated by Fe (III)-carboxylate complexes applied to degradation of landfill leachate. J. Environ. Chem. Eng. 5, 4462-4470.

Sirés, I., Brillas, E., Oturan, M.A., Rodrigo, M.A., Panizza, M., 2014. Electrochemical advanced oxidation processes: today and tomorrow. A review. Environ. Sci. Pollut. Res. $21,8336-8367$.

Sirés, I., Low, C.T.W., Ponce de Leon, C., Walsh, F.C., 2009. The deposition of nanostructured $\beta-\mathrm{PbO}_{2}$ coatings from aqueous methanesulfonic acid for the electrochemical oxidation of organic pollutants. Electrochem. Commun. 12, 70-74.

Southworth, B.A., Voelker, B.M., 2003. Hydroxyl radical production via the photo-Fenton reaction in the presence of fulvic acid. Environ. Sci. Technol. 37, 1130-1136.

Steter, J.R., Brillas, E., Sirés, I., 2016. On the selection of the anode material for the electrochemical removal of methylparaben from different aqueous media. Electrochim. Acta 222, 1464-1474.

Steter, J.R., Brillas, E., Sirés, I., 2018. Solar photoelectro-Fenton treatment of a mixture of parabens spiked into secondary treated wastewater effluent at low input current. Appl. Catal. B Environ. 224, 410-418.
Thiam, A., Salazar, R., Brillas, E., Sirés, I., 2018. Electrochemical advanced oxidation of carbofuran in aqueous sulfate and/or chloride media using a flow cell with a $\mathrm{RuO}_{2}$-based anode and an air-diffusion cathode at pre-pilot scale. Chem. Eng. J. 335, 133-144.

Thiam, A., Sirés, I., Garrido, J.A., Rodríguez, R.M., Brillas, E., 2015. Effect of anions on electrochemical degradation of azo dye Carmoisine (Acid Red 14) using a BDD anode and air-diffusion cathode. Separ. Purif. Technol. 140, 43-52.

Vatanpour, V., Daneshvar, N., Rasoulifard, M.H., 2009. Electro-Fenton degradation of synthetic dye mixture: influence of intermediates. J. Environ. Eng. Manag. 19, 277-282.

Wang, A., Qu, J., Liu, H., Ru, J., 2008. Mineralization of an azo dye Acid Red 14 by photoelectro-Fenton process using an activated carbon fiber cathode. Appl. Catal. B Environ. 84, 393-399.

Yahya, M.S., Oturan, N., El Kacemi, K., El Karbane, M., Aravindakumar, C.T., Oturan, M.A., 2014. Oxidative degradation study on antimicrobial agent ciprofloxacin by electro-Fenton process: kinetics and oxidation products. Chemosphere 117, 447-454. 